\title{
Multinodular and Vacuolated Pattern
}

National Cancer Institute

\section{Source}

National Cancer Institute. Multinodular and Vacuolated Pattern. NCI Thesaurus. Code C129426.

An architectural pattern characterized by the presence of neoplastic cells forming multiple nodules with prominent vacuolation. 